\title{
INQUIRY PRACTICES IN MALAYSIAN SECONDARY CLASSROOM AND MODEL OF INQUIRY TEACHING BASED ON VERBAL INTERACTION
}

\author{
${ }^{1}$ Winnie Sim Siew Li \& 2Mohammad Yusof Arshad \\ ${ }^{1 \& 2}$ Faculty of Education \\ Universiti Teknologi Malaysia
}

${ }^{1}$ Corresponding author: winniesim50@gmail.com

\begin{abstract}
Purpose - Inquiry teaching has been suggested as one of the important approaches in teaching chemistry. This study investigates the inquiry practices among chemistry teachers.

Method - A combination of quantitative and qualitative study was applied in this study to provide detailed information about inquiry teaching practices. Questionnaires, semi-structured interviews and field notes were used. 23 chemistry teachers participated in this study. 92 chemistry lessons were audio and video recorded, which subsequently were transcribed in verbatim. By applying descriptive statistics, the frequencies and percentages of each category in the observation instrument were determined.
\end{abstract}

Findings - Most of the questions made by the teachers and students were closed-ended questions. Teachers in this study practised waittime after asking questions. Meanwhile, it was found that most of the students' questions were followed by answer given by the teacher and the sequence after students' answers was followed by explanation from the teacher. Students were merely following teacher's explanation or procedures in text book before carrying out experiment. The mean of students' ability to provide further explanation was very low. 
Significance - A model of inquiry teaching based on verbal interaction was proposed as a guide for chemistry teachers to implement inquiry teaching in order to be in line with the Malaysian National Science Education Standards.

Keywords: Inquiry teaching, wait-time, verbal interaction, macroscopic, submicroscopic, symbolic, multiple levels of representation.

\section{INTRODUCTION}

Inquiry teaching has been continuously suggested as one of the teaching approaches in Malaysia since 1972. In 1972, modern pure science subjects, i.e. chemistry, physics and biology were introduced in ten secondary schools. Syllabus used were modified based on Nuffield ' $O$ ' Level from England and was then named as Modern Chemistry, Modern Physics and Modern Biology respectively (Chin, 2004). Among the objectives outlined in the syllabus was application of inquiry approach, student-centred and activity-focused. However, inquiry teaching at that time could not be implemented successfully due to lack of physical facilities such as apparatus and availability of laboratories (Tamby Subahan, 1999).

In 1989, an integrated curriculum for secondary schools was introduced. The aim of this curriculum was to provide and enhance students with knowledge and scientific skills, as well as to equip students with scientific values (Sulaiman Ngah, 1998). In order to achieve the objectives, inquiry approach is required. Hence, revised science curriculum which emphasizes on thoughtful learning was introduced in 2003 (Ministry of Education, 2002). To ensure improvement in Malaysia's performance in the next Trends in International Mathematics and Science Study (TIMSS) and Programme for International Student Assessment (PISA) cycle, High Order Thinking Skills were emphasised (Ministry of Education, 2012), which inquiry approach had been suggested as one of the teaching approaches in order to enhance thoughtful learning and inculcate higher order thinking skills. To ensure improvement in Malaysia's performance in the next Trends in International Mathematics and Science Study (TIMSS) and Programme for International Student Assessment (PISA) cycle, High Order 
Thinking Skills (HOTS) were emphasised (Ministry of Education, 2012). In order to implement HOTS, inquiry approach has been suggested as one of the teaching approaches in order to enhance thoughtful learning and inculcate higher order thinking skills.

This approach which emphasises on thinking is very important in producing students who are capable to think and communicate scientifically, which are essential to produce students that are competitively competent at international level.

Currently, inquiry teaching remains as one of the main teaching approaches in teaching chemistry (Curriculum Development Centre, 2005, 2006, 2012, 2013). Inquiry approach is one of the best approaches in teaching science subjects (Melville \& Bartley, 2010). Furthermore, reformation in science and mathematics education had also emphasised this teaching approach (Audet \& Jordan, 2003; Aulls $\&$ Shore, 2008) as this approach focused on active participation of students, ability of the students to ask scientifically oriented questions (National Research Council, 2000; Curriculum Development Centre, 2001a) and most importantly students' involvement in investigation to find the solutions to scientific questions (National Research Council, 2000; Curriculum Development Centre, 2001; Zurida, Syarifah Norhaidah, \& Mohd. Ali, 2005) which had been proven to enhance students' thinking skills (Mumba, Chabalengula, \& Hunter, 2007; Minner, Levy, \& Century, 2010; Opara \& Oguzor, 2011) and students' science process skills (Lunetta, Hofstein, \& Clough, 2007; Simsek \& Kabapinar, 2010).

Inquiry teaching emphasises thorough understanding of subject matter. In learning chemistry, understanding of subject matter of multiple representation levels, namely macroscopic, submicroscopic and symbolic are vital. Macroscopic refers to phenomenon that can be seen using senses; submicroscopic focused on particulate theory of matter, in terms of atom, molecule or ion; and symbolic, focused on formula and equation (Johnstone, 1991, 2000; Beall, Trimbur, \& Weininger, 1994; Limniou \& Papadopoulos, 2011; Jaber \& BouJaoude, 2012). Students should be able to understand and master the chemistry concepts at macroscopic, submicroscopic and symbolic levels. They should also be able to integrate between these multiple representation levels to ensure thorough understanding 
of chemistry concepts. This means that they could link what they observe (macroscopic) and able to explain using particulate theory of matter (submicroscopic level) as well as writing chemical equations (symbolic level).

Although the benefits of inquiry approach to students were widely known, only a handful of teachers applied this approach in their teaching (Keys \& Bryan, 2001). Furthermore, the implementation of inquiry approach by these teachers was based on their own understanding of this approach, as reported by Keys and Bryan (2001) and Llewellyn (2011), which were not in line with the National Science Education Standards (National Research Council, 2000). In Malaysia, there was a gap between implementation of teaching approach by teachers and as required in science curriculum (Curriculum Development Centre, 2001b; Noor Akmar, 2007; Nurfaradilla, Zakiah, Shanti \& Lilia, 2010).

Inquiry practices must be practiced effectively in order to ensure quality of education. Although there was vast research on inquiry teaching, nevertheless, there was lack of research conducted on the process of inquiry teaching by teachers who applied this approach. One way to investigate the effectiveness of inquiry teaching is through verbal interaction. Verbal interaction is anything that is being uttered and this type of interaction could be used to investigate process of interaction that occurred in classroom (Flanders, 1970; Eggleston, Galton, \& Jones, 1975; Malamah-Thomas, 1987; Mohamed Najib \& Mohammad Yusof, 1995; Brandon, Taum, Young \& Pottenger, 2008). Verbal interaction could be in the form of teacher's question, teacher's statement, student's question, student's statement and silence or confusion (Flanders, 1970; Malamah-Thomas, 1987; Mohamed Najib, 1997). The essential component of inquiry teaching is questioning. Teachers should ask open type questions which trigger students to think. Meanwhile, students should be able to ask scientifically oriented question, open question which leads them to carry out investigation to find answer to scientifically oriented question. Open question involves divergent and evaluation thinking (Martin, Sexton, Franklin, Gerlovich \& McElroy, 2009). Besides that, in inquiry teaching, teachers should allocate silence after asking question and after students' response. This silence is also known as wait-time. Wait-time is important to provide sufficient time for students to think and response to questions asked by teachers (Rowe, 
1974, 1986; Haigh, 2010). There are two types of wait-time; waittime one, silence after teacher's question and wait-time two, silence after students' response. Hence, this study investigates the sequence after teacher's questions and students' response as well as type of teacher's and students' questions.

Based on Figure 1, there are five essential features of inquiry classroom. The five essential features include learner engagement in scientifically oriented questions, learner gives priority to evidence in responding to questions, learner formulates explanations from evidence, learner connects explanation to scientific knowledge and learner communicates and justifies explanation (National Research Council, 2000). The first essential feature is students should be able to ask scientifically oriented questions. Second feature is students involve in group activities to collect data and evidence in responding to questions investigated. Students should also be able to provide further explanation based on the third, fourth and fifth features of inquiry classroom. Hence, the study also investigates group activities and students' ability to provide further explanation.

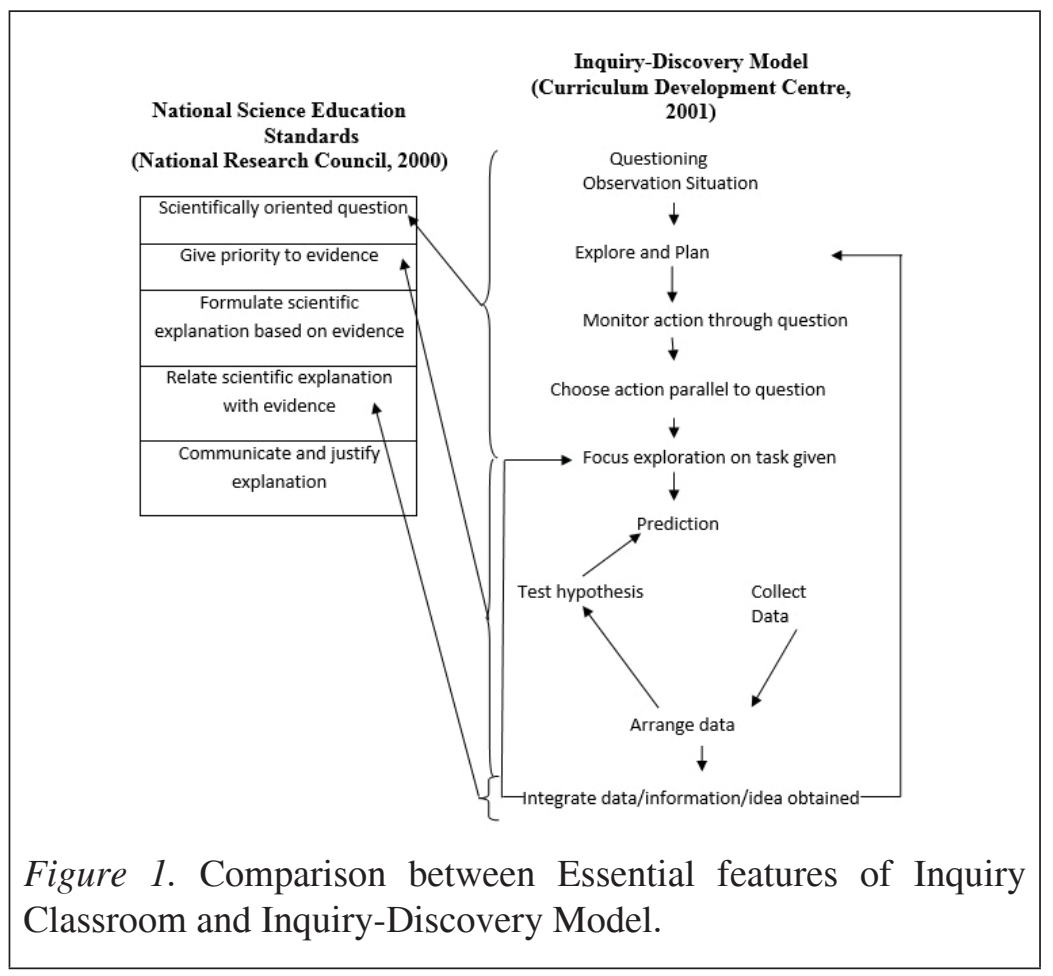


In Malaysia, inquiry model that has been introduced is InquiryDiscovery Model by Curriculum Development Centre (2001a). In comparison with the five essential features of inquiry classroom stated in National Science Education Standards (National Research Council, 2000), Inquiry-Discovery Model has yet to fulfil two essential features as shown in Figure 1. Specifically, there is still lack of focus on how learner formulates explanations from evidence and how learner communicates and justifies explanation. Hence, a model of inquiry teaching practices based on verbal interaction is proposed based on findings obtained from this study to shed some light to chemistry curriculum developers, as well as to chemistry teachers.

\section{OPERATIONAL DEFINITIONS}

Inquiry teaching- This approach is based on scientific activity and involves student and application of five aspects of inquiry learning according to National Science Education Standards.

Wait-time - 'silence' after asking questions and after students' response. Wait-time one is 'silence' after teacher's question. Waittime two is silence after students' response.

Verbal interaction - Refers to talk between teacher and student, between students and other students. This may be in the form of teacher's and students' questions and statements.

Multiple levels of interaction - Understanding of chemistry concepts needs conceptual understanding at three perspectives; at macroscopic, submicroscopic and symbolic levels.

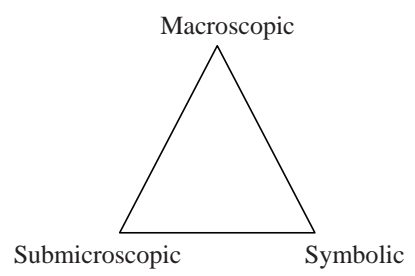

Macroscopic - Understanding of chemistry concepts which focuses on materials and phenomena that can be seen with eyes.

Submicroscopic - Understanding of chemistry concepts at particulate theory of matter (atom, molecules or ions).

Symbolic - Understanding of chemistry concepts which focuses on formula and equation. 


\section{RESEARCH OBJECTIVES}

This study aims to investigate on the current inquiry practices among chemistry teachers with the purpose to meet the following research objectives.

1. To determine inquiry teaching practices among chemistry teachers in terms of:

a) Type of teacher's question and type of students' question.

b) Sequence after teacher's question.

c) Sequence after students' response.

d) Group activity.

e) Students' ability to provide further explanation on concepts discussed.

2. To propose model of inquiry teaching based on verbal interaction in chemistry.

\section{METHODOLOGY}

\section{Participants}

23 chemistry teachers from 13 different secondary schools in Kuala Lumpur, Malaysia were involved in this study. Out of these 23 participants, 21 teachers $(91.3 \%)$ have bachelor degree while 2 teachers $(8.7 \%)$ have master degree. 22 teachers $(95.7 \%)$ were specialised in chemistry. Non-participating observation was applied in this study. These teachers were observed four times; twice for theory and twice for practical lessons. These observations were recorded after obtaining consent from the teachers.

\section{Instrument}

In this study, an observation instrument known as Observation Instrument in Inquiry Teaching through Verbal Interaction (OIITVI) was applied. This observation instrument consists of 50 categories and was built based on modification of previous existing classroom observation instruments, which include Flanders' Interaction Analysis Categories (Flanders, 1970), Science Teaching Observation Schedule (Eggleston, Galton, \& Jones, 1975), Observation Schedule (Mohamed Najib, 1997), Inquiry Science Observation Coding Sheet (Brandon et al., 2008) and Observation Instrument based on 
Constructivism Approach (Tay, 2010). This OIITVI was introduced to cater for the need to investigate the practices of inquiry teaching approach among chemistry teachers. Furthermore, the above mentioned existing classroom observation instruments do not include all current process of science skills and wait-time one and wait-time two aspects which are vital in inquiry teaching practices. Apart from the observation instrument, semi structured interview and documents, which include teacher's record book and worksheet were analysed to increase the validity and the reliability of this study.

Content validity and face validity of the observation instrument, OIITVI were derived from two senior lecturers specialised in chemistry education and an expert chemistry teacher. Inter-rater reliability was applied as suggested by Creswell (2008) as the data collection were done solely by the researcher. Prior to actual data collection, the researcher together with two senior chemistry education lecturers had categorised a recorded 30 minutes using the OIITVI instrument. Kappa value had been applied to express the agreement between observers. Calculated Kappa values derived were .977 and .808 for the first and second lecturer respectively. According to Viera and Garrett (2005), these values showed high agreement between the observers. In order to ensure the realibility of data obtained from OIITVI, recorded chemistry lessons were listened twice.

\section{Data Analysis}

Descriptive statistics was used to determine frequency and percentage of each category. Based on categories in the observation instrument of OIITVI, chemistry lessons were first categorised. Frequency of the observed category was counted. Then, the frequency of the observed category divided by the total frequency of all categories observed multiply with $100 \%$ to obtain the percentage of the observed category. In this study, four observations have been derived. Mean has been calculated to find the average of the four observations made. This method has also been applied in other studies on verbal interaction (Tay, 2010). Each chemistry lesson recorded was transcribed to verbatim to determine the type of questions asked by teachers and students, sequence after teacher's question as well as sequence after student's response. 


\section{FINDINGS AND DISCUSSION}

This part will discuss on the findings based on research objectives. First part is on teacher's question and type of students' questions. As mentioned earlier, there are two types of questions, open-ended and close-ended question. In inquiry classroom, students are expected to ask open-ended question and of high order thinking questions, which involves divergent and evaluation thinking.

\section{Type of teacher's question and type of students' question}

Teacher's question and students' question (94.30\%) were mainly in closed-ended questions as shown in Figure 2.

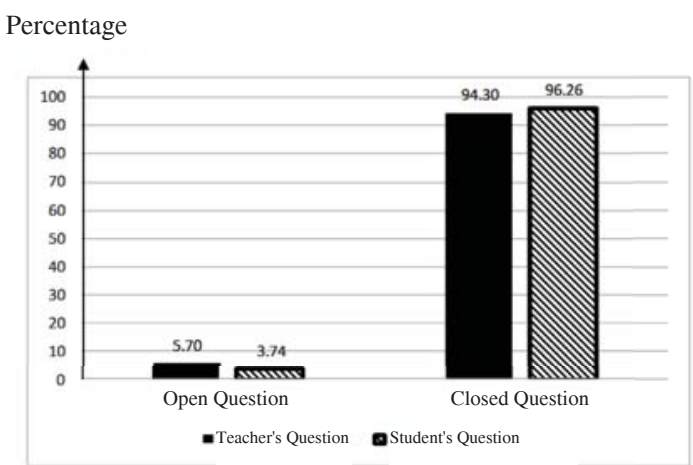

Figure 2 . Type of Teacher's Question and Student's Question

Based on Table 1, 5912 questions (52.64\%) asked by teachers were mainly involved cognitive-memory thinking questions.

Table 1

Percentage of Teacher's Questions According to Type of Thinking Required

\begin{tabular}{lccccccc}
\hline \multicolumn{3}{c}{ Open-ended question } & \multicolumn{4}{c}{ Closed-ended question } \\
\hline $\begin{array}{c}\text { Type of } \\
\text { question }\end{array}$ & Evaluation & Divergent & Total & Convergent & $\begin{array}{c}\text { Cognitive- } \\
\text { memory }\end{array}$ & $\begin{array}{c}\text { Total } \\
\text { Overall } \\
\text { Total }\end{array}$ \\
\hline Total & 9 & 632 & 641 & 4679 & 5912 & 10591 & 11232 \\
Percentage $(\%)$ & 0.08 & 5.63 & 5.70 & 41.66 & 52.64 & 94.30 & 100.00 \\
\hline
\end{tabular}


This finding was further supported by previous studies conducted by $\mathrm{Ng}$ and Siow (2003), Effendi and Zanaton (2007), AlbergariaAlmedia and Teixera-Dias (2011), Nisa and Khan (2012). Teacher's questions were merely to check on student's understanding and facts as reported by Wragg and Brown (2001), and Chin (2007). Example of questions asked by teachers: [Context of discussion: Heating of copper (II) carbonate]

Teacher: Copper (II) carbonate, green colour. So, green colour change to what colour?

[Respondent R01: Practical Class]

[Context of discussion: Nomenclature of carbon compounds]

Teacher: What is the general formula for alcohol?

[Respondent R06: Theory Class]

Similarly, student's questions $(91.56 \%)$ were also mainly involved cognitive-memory thinking question, as shown in Table 2.

Table 2

Percentage of Student's Questions According to Type of Thinking Required

\begin{tabular}{lccccccc}
\hline & \multicolumn{3}{c}{ Open-ended question } & \multicolumn{5}{c}{ Closed-ended question } \\
\hline $\begin{array}{c}\text { Type of } \\
\text { question }\end{array}$ & Evaluation & Divergent & Total & Convergent & $\begin{array}{c}\text { Cognitive- } \\
\text { memory }\end{array}$ & Total & $\begin{array}{c}\text { Overall } \\
\text { Total }\end{array}$ \\
\hline Total & 0 & 55 & 55 & 69 & 1345 & 1414 & 1469 \\
Percentage $(\%)$ & 0 & 3.74 & 3.74 & 4.70 & 91.56 & 96.26 & 100.00 \\
\hline
\end{tabular}

Example of questions asked by students:

[Context of question: concept of electrochemistry]

Student 1: $\quad$ Teacher, if we just say anode is positive? 
[Context of discussion: Teacher explaining materials to make soap] Teacher: $\quad$ Ok, first thing we need is the oil, palm oil.

Student 1: $\quad$ Palm oil?

[Respondent R07: Practical Class]

These questions do not reflect real inquiry teaching approach. In inquiry approach, students should be able to ask scientifically oriented questions. In inquiry teaching practices, open-ended questions which requires high order thinking are to be adopted. Findings from this study differ with findings from Hofstein et al. (2005) study. They observed that students who had experience in inquiry teaching and learning had asked high order thinking questions. Overall, type of questions asked by teachers and students in this study were found to be deviated from National Science Education Standards (National Research Council, 2000).

\section{Sequence after teacher's question}

Sequence after teacher's questions is important to be investigated in view that it will provide information whether the teacher practises wait-time one. Based on the data, the highest mean after teacher's question was derived from teacher's questions followed by students' answer, 4.03 (see Table 3).

Table 3

Mean of Sequence of Verbal Interaction after Teacher's Question

\begin{tabular}{lc}
\hline Sequence of verbal interaction & Mean \\
\hline Teacher's question followed by student's answer & 4.03 \\
Teacher's question followed by teacher's explanation & 0.94 \\
Teacher's question followed by wait-time one & 0.83 \\
\hline
\end{tabular}

\section{Teacher's question followed by student's answer}

Example of transcript of lesson which showed the above sequence as follows: 
[Context of discussion: Carbon Compound (Alcohol)]

Teacher:

Let say I want to draw. I want to draw.., alcohol that has two carbons, that means $n$ equals to?

Student:

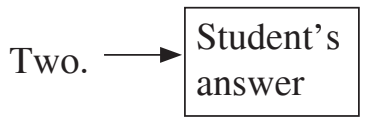

[Respondent R06: Theory Class]

\section{Teacher's question followed by teacher's explanation}

Mean for the above sequence (0.94) was slightly higher than percentage obtained from study conducted by Tay (2010), which was 0.53 . This shows that chemistry teachers in this study had given emphasis in providing explanation after asking question. Example of excerpt of transcript as follows:

[Context of lesson: Calculating empirical formula]

Teacher:

$$
\begin{aligned}
& \text { Question number 2, they give the } \\
& \text { percentage, right? }
\end{aligned}
$$

Teacher's question

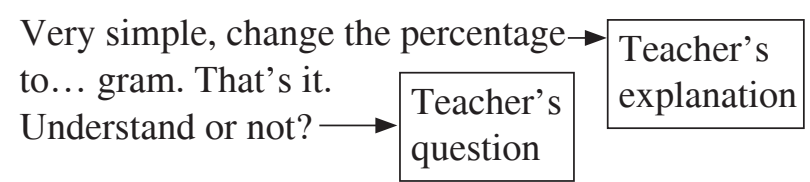

Percentage... change it to... gram.

So, you assume the compound is...
100 gram.

So, how many percent... will be $\longrightarrow \begin{aligned} & \text { Teacher's } \\ & \text { question }\end{aligned}$
how many gram... ok?

So, you just change the percentage $\rightarrow$ Teacher's to gram, that's all. explanation 


\section{Teacher's question followed by wait-time one}

Respondents in this study seemed to practise wait-time one, since this sequence of verbal interaction recorded the third highest mean (0.83). The value obtained in this study was higher compared to 0.25 obtained by Tay (2010). Practice of wait-time one among chemistry teachers in this study showed a positive finding as inquiry teaching emphasises on wait-time.

Example of excerpt of transcript:

[Context of questions: Reactions at anode of electrochemical cell]

Teacher:

At the anode, what happen?

What happen to the anode? (48:54)

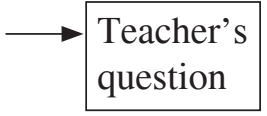

(Wait-time one: three seconds)

Student 1: $\quad$ Thinner. (48:57)

[Respondent R19: Practical Class]

Silence for the purpose of wait-time in inquiry teaching is very important as it allows students to think (Colburn, 2000; Friedl \& Koontz, 2005). Hence, these teachers had shown effort in practising wait-time one after asking question.

\section{Sequence of verbal interaction after students' response}

Students' response refers to either student's question or student's statement. In this study, sequence of verbal interaction after student's response looked into sequence of verbal interaction after student's question as well as sequence of verbal interaction after student's statement.

\section{Sequence after student's question}

Two sequences of verbal interaction after student's question that showed highest mean were teacher answers student's question and other students answering student's question as shown in Table 4. 
Table 4

Mean of Sequence of Verbal Interaction after Student's Question

\begin{tabular}{lc}
\hline Category & Mean \\
\hline Student's question followed by teacher giving answer & 4.03 \\
Student's question followed by other student(s) giving answer & 0.94 \\
\hline
\end{tabular}

Example of transcript that reflects the above sequence is as follows:

\section{Student's question followed by teacher giving answer}

[Context of question and answer: Student asked for confirmation of material needed to carry out experiment]
Student 1:
Palm oil?
$\longrightarrow$ Student'squestion
Teacher:
Yes, palm oil.
Teacher giving answer

\section{Student's question followed by other student(s) giving answer}

[Context of question and answer: Student asked for confirmation of the molarity of material needed to carry out experiment]
Student 1:
This one? solution to teacher]
Student 2: $\quad$ Zero point five molar copper (II) sulphate.

$\longrightarrow$ Student'squestion

[Student showed a beaker containing

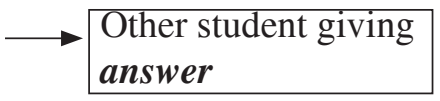

Student(s) giving answer to another student's question showed student's initiative to response and involved in the learning process.

\section{Sequence of verbal interaction after student's statement}

Two highest sequence of verbal interaction after student's statement were teacher giving explanation and wait-time two as shown in Table 5. 
Table 5

Mean of Sequence of Verbal Interaction after Student's Statement

\begin{tabular}{lc}
\hline Category & Mean \\
\hline Student's statement followed by teacher giving explanation & 0.98 \\
Student's statement followed by wait-time two & 0.53 \\
\hline
\end{tabular}

Example of transcript that showed the above sequence :

Student's statement followed by teacher giving explanation

[Context of lesson: Periodic Table: Electron arrangement]

Teacher: Helium?

Student 1: $\quad$ Two. $\longrightarrow$ Student's statement

Teacher: $\quad$ Lithium... proton number is

three. So, the electron

arrangement is two dot one.

Teacher giving explanation

\section{Student's statement followed by wait-time two}

[Context of lesson: Procedures to carry out experiment to determine empirical formula of magnesium oxide]

Teacher: $\quad$ ok, then...?

Students: $\quad$ Repeat the process of heating, cooling and weighing until a constant mass is obtained. $(5: 48)$ Student's statement

(after three seconds)

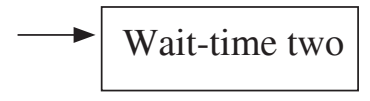

Teacher: $\quad$ Ok, number eleven? (5:51)

In conclusion, teachers had adopted the practice of wait-time two after student's statement which reflected a positive indicator of inquiry teaching practices among the teachers. 


\section{Group activity}

Group activity refers to activities such as students conducting experiment or discussion in group assigned by teachers. Group activity is emphasised in inquiry approach practices as students need to gather data or evidence to provide possible answers to scientifically oriented questions investigated. Mean of overall group activity was $18.09 \%$ of total verbal interaction that occurred during chemistry lessons observed. Nevertheless, based on the memo, students were merely either following instruction given by teachers or adhering procedures stated in text book or hand-on practical book. This finding is similar to findings from study carried out by Po (2011). Hence, these "cookbook" experiments do not reflect actual teaching practice (Llewellyn, 2005). Students are expected to be able to identify problems to be investigated, suggest possible hypotheses, design possible experiments, analyse and make conclusion based on data obtained.

\section{Students' ability to provide further explanation of concepts discussed}

One of the characteristics of inquiry teaching and learning is students should be able to provide further explanation on concepts discussed (National Research Council, 2000). Overall, this study founds that the mean of student's ability to provide further explanation was very low at 0.08 , which indicates that this category contributes only $0.08 \%$ of the total verbal interaction that occurred during chemistry lessons observed. This was due to most of the teacher's questions were of close-ended questions which required short predetermined answers, a word or two. This scenario of question and answer session which required short answers was also reported by Tay (2010). Example of questions and answers sessions during teaching and learning chemistry observed in this study were as follows:

$\begin{array}{lll}\text { Teacher } & : & \text { Group seventeen, what do we call it? } \\ \text { Students } & : & \text { Halogen. } \\ \text { Teacher } & : & \text { Halogen. Group eighteen? } \\ \text { Students } & : & \text { Noble gases. }\end{array}$

The very low mean value obtained from this study reflects that there is still room for improvement in terms of practice of inquiry teaching 
approach among chemistry teachers. Hence, a model of inquiry teaching based on verbal interaction is proposed as a guideline for teachers to implement inquiry approach to be in line with the National Science Education Standards.

\section{Model of Inquiry Teaching Based on Verbal Interaction}

Findings from this study revealed that teacher's questions and students' questions were mainly closed-ended question, which required mainly cognitive-memory thinking. In inquiry teaching, students should ask open-ended questions which required divergent and evaluation thinking (see Figure 3). Chemistry teachers in this study practised wait-time one and wait-time two. This means that they allocate time after posed a question to students and after students' responses (questions / answers). Nevertheless, group activity carried out were merely of 'cookbook' experiments. This 'cookbook' activity does not illustrate real inquiry teaching. In inquiry teaching and learning process, students should be given the opportunity to generate ideas on hypothesis, to carry out possible procedures to test the hypothesis and in making conclusion, which are more student-centred. Besides that, mean of student's ability to provide further explanation was very low (0.08). This finding also showed that students could only provide a short predetermined answer, a word or two based on teacher's questions. Students were not capable to ask scientifically oriented questions and formulate explanation form the evidence gathered. The lessons were teachercentred, which teachers imparts the knowledge to students.

Findings from this study revealed that inquiry teaching has not been implemented according to National Science Education Standards. Hence, a model of inquiry teaching based on verbal interaction was proposed to ensure inquiry teaching carried out by chemistry teachers are in line with the National Science Education Standards and suggested on how inquiry teaching and learning should take place in chemistry lessons based on verbal interaction perspective. This model consists of three main components, a triangle which represents multiple levels of representations in chemistry, inquiry teaching and verbal interaction that need to be emphasised in inquiry teaching, which is supported based on findings of this study and literature review (see Figure 3). 


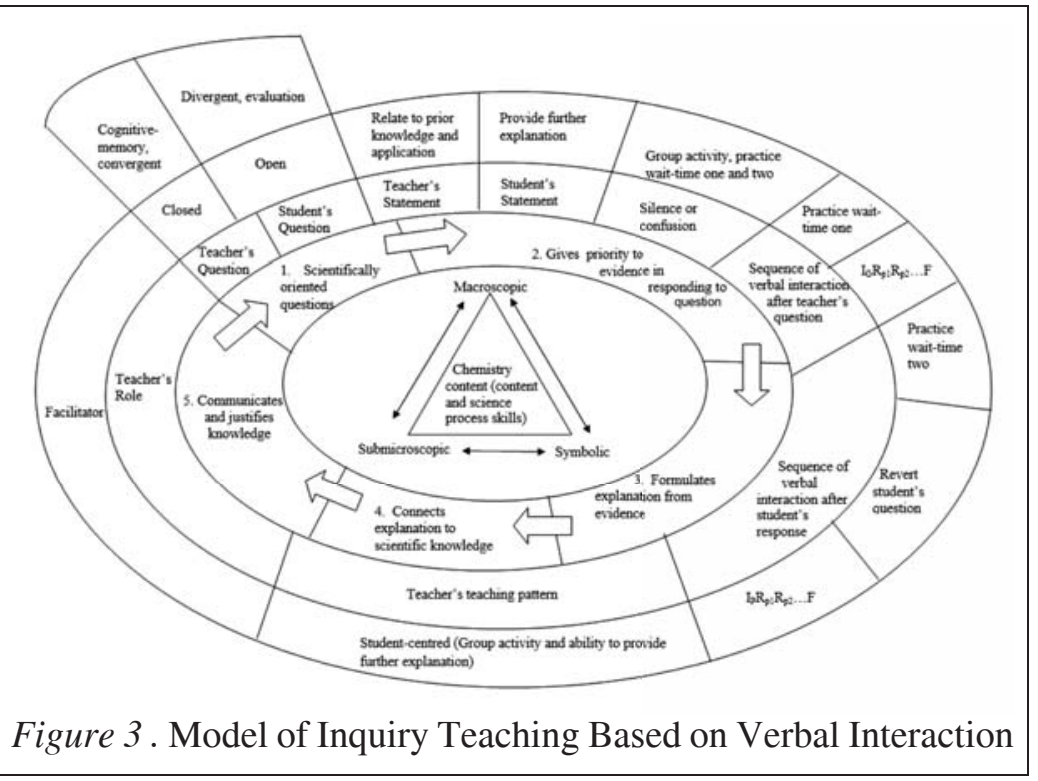

[Note: $I_{G} R_{P 1} R_{P 2} \ldots F$ (after teacher's question $\left(I_{G}\right)$, followed by student 1 's response $\left(\mathrm{R}_{\mathrm{P} 1}\right)$, followed by student 2's response $\left(\mathrm{R}_{\mathrm{P} 2}\right)$ and this sequence continues (represented by ...) and ends with students giving feedback $(\mathrm{F}) ; \leftrightarrow$ - needs to integrate between multiple levels of representation; $\mathrm{I}_{\mathrm{P}} \mathrm{R}_{\mathrm{G}} \mathrm{R}_{\mathrm{P} 1} \mathrm{R}_{\mathrm{P} 2} \ldots \mathrm{F}$ (after student's question or student's statement $\left(\mathrm{I}_{\mathrm{P}}\right)$, follows by teacher reverts the response to class $\left(\mathrm{R}_{\mathrm{G}}\right)$, followed by student 1's response $\left(\mathrm{R}_{\mathrm{P} 1}\right)$, followed by student 2's response $\left(\mathrm{R}_{\mathrm{P} 2}\right)$ and this sequence continues (represented by ...) and ends with students giving feedback $(\mathrm{F})]$

\section{(i) Triangle of multiple levels of representation in chemistry}

This triangle is placed at the centre of this model, which acts as the core learning of chemistry. Chemistry concepts, which comprise of content and science process skills should be learned at macroscopic, submicroscopic and symbolic level. In addition to that, students should be able to integrate between these multiple levels of representation to enhance their understanding and application of chemistry concepts. The symbol $(\leftrightarrow)$ ) shows that teachers should assist students in integrating concepts learned at multiple levels of representation.

\section{(ii) Inquiry teaching}

Five features of inquiry classroom that need to be emphasised in inquiry teaching are as follow:- 
1. Students should be able to ask scientifically oriented questions.

2. Gives priority to evidence in responding to question.

3. Formulates explanation from evidence.

4. Connects explanation to scientific knowledge.

5. Communicates and justifies knowledge.

This inquiry teaching approach begins with scientifically oriented question and this process is continuous which is showed by $(\Rightarrow)$. Next, this model also includes how inquiry teaching approach should be practiced based on verbal interaction.

\section{(iii) Inquiry Practice Based on Verbal Interaction}

This model include inquiry based on verbal interaction, which covers teacher's question, teacher's statement, student's question, student's statement, silence or confusion, sequence of verbal interaction after teacher's question, sequence of verbal interaction after student's response, teaching pattern and teacher's role.

a) Teacher's question, teacher's statement, student's question, student's statement, silence or confusion

Based on Figure 3, teacher's question and student's questions should be more of open-ended question which requires divergent and evaluation thinking. Furthermore, the type of questions asked should encourage students to search for more information (Nor Aziah, Zuaini, \& Wan Nordin, 2011). Besides that, questions asked should involve multiple levels of representations. Teachers should try to relate to student's prior knowledge and application to daily life in teaching chemistry concepts. Students should be able to provide further explanation on concepts discussed. Group activity which focused on students carrying out experiment or investigation should be emphasised. Teachers should also allocate silence for the purpose of wait-time after asking questions (wait-time one) as well as after student's response (wait-time two) to allow students to think and give response.

b) Sequence of verbal interaction after teacher's question

Teachers should practice wait-time one after asking questions. In this model, suggestion for verbal interaction after teacher's question is $I_{G} R_{P 1} R_{P 2} \ldots F$. This sequence means that after teacher's question 
$\left(\mathrm{I}_{\mathrm{G}}\right)$, followed by student 1's response $\left(\mathrm{R}_{\mathrm{P}}\right)$, followed by student 2's response $\left(\mathrm{R}_{\mathrm{P} 2}\right)$ and this sequence continues (which is represented by ...) until student had given feedback (F).

c) Sequence of verbal interaction after student's response

Student's response refers to either students asking question or students giving answers to student's question. Teachers should allocate silence after student's response (wait-time two) to encourage other students to response. In this study, sequence of verbal interaction after student's question was IRg (student's question followed by teacher's giving answer). In order to be in line with the need of inquiry teaching, sequence of verbal interaction suggested in this model is $I_{P} R_{P 1} R_{P 2} \ldots F$. This sequence means that after student's question of statement $\left(\mathrm{I}_{\mathrm{P}}\right)$, followed by student 1 giving response $\left(\mathrm{R}_{\mathrm{P} 1}\right)$, continued by student 2's response $\left(\mathrm{R}_{\mathrm{P} 2}\right)$, and this sequence continues (which is represented by ...) until the student has given feedback (F). Discussion should be enhanced among students, which is vital in inquiry teaching practices.

\section{d) Teaching Pattern}

Teaching pattern should be student-centred which focuses on students' activities and students' ability to provide further explanation of chemistry concepts discussed.

\section{e) Teacher's Role}

Teacher should acts as facilitator (inquirer) in guiding students in asking scientifically oriented questions, gives priority to evidence in responding to question, formulates explanation from evidence, connects explanation to scientific knowledge, communicates and justifies knowledge. In this way, students are motivated and encouraged to actively participate in teaching and learning process.

\section{CONCLUSION}

Teachers' teaching approaches in the process of teaching and learning is prevalent in producing quality students. They hold responsibility in order to implement teaching approaches suggested 
in the curriculum to ensure quality of teaching and learning process. Quality education is required in producing better students which are competitive at national and at international level. Findings in this study should serve as a wakeup call for educators as it shows that there are many aspects in inquiry practices that need to be relooked. In conclusion, teachers need to have "correct" and positive understanding of inquiry practices to enhance this approach for the betterment of students.

\section{REFERENCES}

Audet, R. H., \& Jordan, L. K. (2003). Standards in the classroom: An implementation guide for teachers of science and mathematics. Thousand Oaks, California: Corwin Press, Inc.

Aulls, M. W., \& Shore, B. M. (2008). Inquiry in education: Volume 1. New York: Lawrence Erlbaum Associates.

Beall, H., Trimbur, J., \& Weininger, S. J. (1994). Mastery insight and the teaching of chemistry. Journal of Science Education and Technology, 3(2), 99-105.

Brandon, P. R., Taum, A.K.H., Young, D. B., \& Pottenger III, F.M. (2008). The development and validation of the inquiry science observation coding sheet. Evaluation and Program Planning, 31(3), 247-258.

Chin, C. (2007). Teacher questioning in science classrooms: Approaches that stimulate productive thinking. Journal of Research in Science Teaching, 44(6), 815-843.

Chin, K. G. (2004). Path analytical model of science process skills acquisition among form four students (Unpublished doctoral dissertation). University Malaya, Kuala Lumpur.

Colburn, A. (2000). An inquiry primer. Science Scope, 23(6), 42-44.

Creswell, J. W. (2008). Educational research: Planning, conducting and evaluating quantitative and qualitative research (3rd ed.). Upper Saddle River, New Jersey: Pearson Education.

Curriculum Development Centre (2001a). Nota penerangan pusat latihan kursus orientasi Sains KBSM PuLKOS inkuiri penemuan dalam pengajaran dan pembelajaran sains. Kuala Lumpur: Kementerian Pendidikan Malaysia.

Curriculum Development Centre (2001b). Modul 1: Kemahiran proses Sains. Kuala Lumpur: Kementerian Pendidikan Malaysia. 
Curriculum Development Centre (2005). Curriculum specification chemistry form four. Putrajaya: Ministry of Education, Malaysia.

Curriculum Development Centre (2006). Curriculum specification chemistry form five. Putrajaya: Ministry of Education, Malaysia.

Curriculum Development Centre (2012). Curriculum specification chemistry form four. Putrajaya: Ministry of Education, Malaysia.

Curriculum Development Centre (2013). Curriculum specification chemistry form five. Putrajaya: Ministry of Education, Malaysia.

Effendi Zakaria \& Zanaton Ikhsan (2007). Promoting cooperative learning in science and mathematics education: A Malaysian perspective. Eurasia Journal of Mathematics, Science and Technology Education, 3(1), 35-39.

Eggleston, J. F., Galton, M., \& Jones, M. E. (1976). Processes and products of science teaching. London: Macmillan Education.

Flanders, N.A. (1970). Analyzing teaching behaviour. USA: Addison-Wesley.

Friedl, A. E., \& Koontz, T. Y. (2005). Teaching Science to children: An inquiry approach (6th ed.). Boston: McGraw Hill.

Haigh, A. (2010). The art of creative teaching primary Science: Big ideas, simple rules. Harlow, England: Pearson.

Hofstein A., Navon O., Kipnis M., \& Mamlok-Naaman R. (2005). Developing students' abilities to ask more and better questions resulting from inquiry-type chemistry laboratories. International Journal of Science Education, 42, 791-806.

Jaber, L. D., \& BouJaoude, S. (2012). A macro-micro-symbolic teaching to promote relational understanding of chemical reactions. International Journal of Science Education, 34(7), 973-998.

Johnstone, A. H. (1991). Why is science difficult to learn? Things are seldom what they seem. Journal of Computer Assisted Learning, 7(2), 75-83.

Johnstone, A. H. (2000). Teaching of chemistry-logical or psychological? Chemistry Education: Research and Practice in Europe, 1(1), 9-15.

Keys, C. W., \& Bryan, L. A. (2001). Co-constructing inquiry-based science with teachers: Essential research for lasting reform. Journal of Research in Science Teaching, 38(6), 631-645. 
Limniou, M., \& Papadopoulos (2011). Teaching strategies and procedures in chemical education based on blended learning. In. J.P. Henderson \& A.D. Lawrence (Eds), Teaching strategies. New York: Nova Science.

Llewellyn, D. (2005). Teaching high school science through inquiry: A case study approach. Thousand Oaks, California: Corwin Press. Llewellyn, D. J. (2011). Differentiated science inquiry. Thousand Oaks, California: Corwin Press.

Lunetta, V. N., Hofstein, A., \& Clough, M.P. (2007). Learning and teaching in the school science laboratory: An analysis of Research, Theory and Practice. In. S.K. Abell, \& F.C. Lederman (Eds), Handbook of research on science education. Mahwah, NJ: Lawrence Erlbaum.

Malamah-Thomas, A. (1987). Classroom interaction. Oxford: Oxford University Press.

Martin, R., Sexton, C., Franklin, T., Gerlovich, J., \& McElroy, D. (2009). Teaching science for all children: An inquiry approach (5th ed.). Boston: Pearson.

Melville, W. and Bartley, A. (2010). Mentoring and community: Inquiry as stance and science as inquiry. International Journal of Science Education, 32(6), 807-828.

Ministry of Education (2002). Surat Pekeliling Ikhtisas Bil. 2/2002: Pelaksanaan Sukatan Pelajaran Yang Disemak Semula Bagi Kurikulum Bersepadu Sekolah Rendah (KBSR) dan Kurikulum Bersepadu Sekolah Menengah (KBSM). 14 January 2002. Kuala Lumpur.

Ministry of Education (2012). Preliminary Report-Executive Summary Malaysia Education Blueprint 2013-2025 Foreword. Retrieved 30 August, 2013 from http://www4. unescobkk.org

Minner, D. D., Levy, A. J., \& Century, J. (2010). Inquiry-based science instruction-What is it and does it matter? Results from a research synthesis years 1984 to 2002. Journal of Research Science Teaching, 47(4), 474-496.

Mohamed Najib Abdul Ghafar (1997). Access and success in higher education. Skudai, Johor: Universiti Teknologi Malaysia.

Mumba, F., Chabalengula, V. M., \& Hunter, W. (2007). Inquiry levels and skills in Zambian high school chemistry syllabus, textbooks and practical examinations. Journal of Baltic Science Education, 6(2), 50-57. 
National Research Council (2000). Inquiry and the National Science Education Standards: A guide for teaching and learning. Washington, DC: National Academic Press.

Ng, S.B. \& Siow, H.L. (2003). Creating a thoughtful classroom: Teaching profile of science teachers in Malaysian secondary school. Paper presented in International Conference of Science and Mathematics Education. 14-16 October. Kuala Lumpur.

Nisa, S., \& Khan, A.A. (2012). Questioning practices in a social studies classroom: A case study from Pakistan. International Journal of Social Science and Education, 2(3), 474-482.

Nor Aziah Abdul Manaf, Zuaini Ishak \& Wan Nordin Wan Hussin (2011). Application of Problem Based Learning (PBL) in a course on financial accounting principles. Malaysian Journal of Learning and Instruction, 8, 21-47.

Noor Akmar Taridi (2007). Pelaksanaan pendekatan inkuiri dalam pengajaran Sains secara eksperimen (Unpublished doctoral dissertation). Universiti Kebangsaan Malaysia, Bangi.

Nurfaradilla Mohamad Nasri, Zakiah Mohd Yusof, Shanti a/p Ramasamy \& Lilia Halim (2010). Uncovering problems faced by science teacher. Procedia Social and Behavioural Sciences, 9, 670-673.

Opara, J.A., \& Oguzor, N.S. (2011). Inquiry instructional method and the school science currículum. Current Research Journal of Social Sciences, 3(3), 188-198.

Po Lai Yin@ Foo Lai Yin (2011).Pelaksanaan pendekatan inkuiri secara eksperimen dalam pengajaran dan pembelajaran Kimia di sekolah menengah (Unpublished master project). Universiti Teknologi Malaysia, Johor.

Rowe, M. (1974). Wait-time and rewards as instructional variables, their influence in language, logic and fate control: Part one - wait time. Journal of Research in Science Teaching, 11(2), 263-279.

Rowe, M.B. (1986). Wait time: Slowing down may be a way of speeding up! Journal of Teacher Education, 37(1), 43-50.

Simsek, P., \& Kabapinar, F. (2010). The effects of inquiry-based learning on elementary students' conceptual understanding of matter, scientific process skills and science attitudes. Procedia Social and Behavioural Sciences, 2(2), 1190-1194.

Sulaiman Ngah Razali (1998). Pengajaran Sains KBSM. Kuala Lumpur: Dewan Bahasa dan Pustaka. 
Tamby Subahan Mohd. Meerah (1999). Syarahan perdana jawatan profesor Universiti Kebangsaan Malaysia. Bilik Jumaah UKM: Universiti Kebangsaan Malaysia.

Tay, C.S. (2010). Amalan konstruktivis guru sains sekolah rendah melalui interaksi verbal bilik darjah (Unpublished doctoral dissertation). Universiti Teknologi Malaysia, Johor.

Wragg, E.C., \& Brown, G. (2001). Questioning in the secondary school. London: Routledge.

Zurida Ismail, Syarifah Norhaidah Syed Idros, \& Mohd. Ali Samsudin (2005). Kaedah mengajar Sains. Pahang: PTS Profesional Publishing. 